\title{
Studi Ohservasional Pasca-Pemasaran Formula Isolat Protein Kedelai pada Bayi dengan Gejala Sugestif Alergi Terhadap Protein Susu Sapi
}

\begin{abstract}
Zakiudin Munasir, ${ }^{1}$ Dina Muktiarti, ${ }^{1}$ Anang Endaryanto, ${ }^{2}$ Ketut Dewi Kumarawati, ${ }^{3}$ Budi Setiabudiawan, ${ }^{4}$ Sumadiono, ${ }^{5}$ Johannes Hudyono, ${ }^{6}$ Melva Louisa, ${ }^{6}$ Arini Setiawati ${ }^{6}$

${ }^{1}$ Departemen Ilmu Kesehatan Anak Fakultas Kedokteran Universitas Indonesia/RSUPN Cipto Mangunkusumo, Jakarta, ${ }^{2}$ Departemen Ilmu Kesehatan Anak Fakultas Kedokteran Universitas Airlangga/RS Dr. Soetomo, Surabaya, ${ }^{3}$ Departemen Ilmu Kesehatan Anak Fakultas Kedokteran Universitas Udayana/RSUP Sanglah, Bali, ${ }^{4}$ Departemen Ilmu Kesehatan Anak Fakultas Kedokteran Universitas Padjadjaran/RS. Hasan Sadikin, Bandung, ${ }^{5}$ Departemen Ilmu Kesehatan Anak Fakultas Kedokteran Universitas Gajah Mada/RSUP Dr. Sardjito, Yogyakarta, ${ }^{6}$ Clinical Study Unit Fakultas Kedokteran Universitas Indonesia, Jakarta.
\end{abstract}

Latar belakang. Fomula berbasis isolat protein kedelai banyak digunakan untuk anak-anak dengan alergi susu sapi di Indonesia. Namun, diperlukan penelitian untuk mendapatkan gambaran penerimaan orangtua dan toleransi saluran cerna pada penggunaan formula isolat protein kedelai.

Tujuan. Pertama, menentukan penerimaan orangtua terhadap pemberian suatu isolat protein kedelai pada bayi yang diduga mengalami alergi terhadap protein susu sapi. Kedua, mengetahui toleransi saluran cerna pada pemberian susu formula tersebut.

Metode. Suatu studi pasca-pemasaran, prospektif, multisenter yang dilakukan di Jakarta, Bandung, Surabaya, Yogyakarta, Solo, dan Denpasar sejak September 2011 sampai April 2012. Subyek berusia antara 6 bulan hingga 1 tahun dengan gejala dugaan alergi terhadap protein susu sapi yang diberikan formula isolat protein kedelai dan diamati selama 4 minggu. Luaran yang diharapkan adalah penerimaan orangtua terhadap pemberian formula isolat protein kedelai dan toleransi saluran cerna terhadap pemberian isolat protein kedelai.

Hasil. Diteliti 534 subyek yang dapat dianalisis selama periode penelitian. Mayoritas orangtua (84\%) merasa puas dengan formula isolat protein kedelai, $83 \%$ orangtua berencana untuk melanjutkan pemberian susu formula karena berkurang $(31,5 \%)$ dan hilangnya gejala yang diduga akibat alergi susu sapi $(32,4 \%)$. Gejala klinis yang diduga akibat alergi terhadap protein susu sapi menurun pada setiap kunjungan berikutnya. Tidak ada efek samping serius yang dilaporkan selama periode penelitian.

Kesimpulan. Penelitian ini menemukan tingkat penerimaan orangtua dan toleransi saluran cerna yang baik terhadap pemberian formula isolat protein kedelai kepada bayi dengan gejala sugestif alergi terhadap protein susu sapi. Formula isolat protein kedelai cukup aman dijadikan sebagai formula alternatif pengganti pada anak dengan alergi susu sapi. Sari Pediatri 2013;15(4):237-43.

Kata kunci: formula isolat protein kedelai, alergi protein susu sapi, penerimaan orangtua, toleransi saluran cerna

\section{Alamat korespondensi:}

DR. Dr. Zakiudin Munasir, Sp.A(K). Divisi Alergi-Imunologi RSUPN

Dr. Cipto Mangunkusumo. Jl. Diponegoro 71, Jakarta 10430. Telp. (021)

3161144, Fax.(021) 3907743. E-mail: zakiudin_minazir@idai.or.id 
$\mathrm{R}$ eaksi simpang terhadap susu sapi terutama sering terjadi pada anak berusia di bawah 1 tahun. Reaksi simpang dapat merupakan reaksi yang dimediasi oleh imunologi yaitu berupa alergi dan reaksi yang tidak dimediasi oleh respon imunologi yaitu berupa intoleransi. Prevalens alergi protein susu sapi berkisar 2\% sampai 3\% dengan manifestasi klinis yang dapat timbul di saluran cerna, saluran napas, kulit, maupun anafilaksis. ${ }^{1}$

Tata laksana utama pada reaksi simpang terhadap protein susu sapi adalah penghindaran protein susu sapi secara ketat. Formula pengganti susu sapi adalah formula hidrolisat ekstensif, formula asam amino, dan formula berbasis isolat protein kedelai. Pilihan pertama formula berbeda-beda di setiap negara. Konsensus yang berlaku di Eropa dan Amerika memilih formula hidrolisat ekstensif sebagai formula pengganti pertama pada anak dengan alergi protein susu sapi. Sedangkan Singapura dan Australia memilih formula berbasis protein isolat kedelai sebagai pilihan pertama formula pengganti pada anak alergi susu sapi. ${ }^{2-5}$

Konsensus yang dikeluarkan oleh Ikatan Dokter Anak Indonesia (IDAI) adalah formula pilihan pertama sebagai pengganti susu sapi pada anak dengan alergi susu sapi adalah formula hidrolisat ekstensif pada kasus dengan gejala klinis ringan-sedang dan formula asam amino pada gejala klinis berat. Namun, apabila terdapat masalah ketersediaan atau harga dari formula hidrolisat ekstensif atau asam amino, maka formula berbasis isolat protein kedelai dapat diberikan pada anak berusia di atas enam bulan. ${ }^{6}$

Beberapa masalah yang sering menjadi perhatian dokter atau orangtua pada penggunaan formula isolat protein kedelai adalah masalah pertumbuhan dan kandungan protein kedelai seperti fitoestrogen. Beberapa penelitian telah membuktikan bahwa pemberian susu kedelai pada bayi cukup bulan ternyata menunjukkan penambahan berat badan dan panjang badan yang normal, kadar protein dan mineralisasi tulang yang normal. ${ }^{7-10}$ Sedangkan pada penelitian fitoestrogen pada formula isolat protein kedelai tidak jelas memberikan dampak negatif terhadap manusia. ${ }^{11}$ Namun demikian, European Society for Pediatric Gastroenterology Hepatology and Nutrition (ESPGHAN) dan American Academy of Pediatrics (AAP) menyatakan belum cukup bukti dampak fitoestrogen pada manusia sehingga belum dapat disimpulkan dan perlu penelitian lebih lanjut. ${ }^{12,13}$

Dalam praktik sehari-hari di Indonesia ternyata penggunaan formula isolat protein kedelai sering diberikan pada anak alergi susu sapi. Hal ini disebabkan karena masalah formula hidrolisat yang tidak selalu mudah didapatkan di seluruh pelosok Indonesia atau masalah harga yang memang cukup mahal. Walaupun formula isolat protein kedelai sangat banyak digunakan, namun belum ada penelitian yang meneliti mengenai penerimaan orangtua terhadap formula isolat protein kedelai dan toleransi saluran cerna anak yang mengonsumsi formula ini.

Penelitian ini adalah penelitian pasca-pemasaran formula Isomil Advance ${ }^{\circledR}$ yang mengandung protein isolat kedelai. Formula ini sudah berada di Indonesia selama lebih dari enam tahun dan belum pernah dilakukan penelitian pasca-pemasaran terhadap formula ini. Luaran penelitian yang ingin dicapai ini adalah penerimaan orangtua terhadap formula ini dan toleransi saluran cerna anak yang mengonsumsi formula Isomil Advance.

\section{Metode}

Penelitian observasi pasca-pemasaran, dilakukan multisenter di Jakarta, Bandung, Surabaya, Malang, Yogyakarta, Solo, dan Denpasar sejak September 2011 sampai April 2012. Kriteria inklusi adalah bayi berusia 6-12 bulan, bayi lahir cukup bulan (usia gestasi 3742 minggu), berat lahir lebih atau sama dengan 2500 gram, bayi mengalami manifestasi klinis yang sugestif alergi terhadap protein susu sapi berdasarkan penilaian klinis peneliti, subyek memakai formula isolat protein kedelai.

Dugaan alergi susu sapi didasarkan faktor-faktor sugestif yang mengarah pada diagnosis alergi susu sapi yaitu dari anamnesis didapatkan adanya asosiasi waktu (timbul gejala alergi apabila minum susu sapi dan gejala menghilang apabila susu sapi dieliminasi dari diet), terdapat riwayat atopi dalam keluarga, terdapat beberapa sistem organ yang terlibat, uji alergi atau indikator inflamasi yang positif (apabila dilakukan), eksklusi intoleransi laktosa, dan tidak ada respons pada pemberian obat-obatan simptomatik/kausal lain. Pemilihan formula diserahkan kepada orangtua secara sukarela, apabila orangtua memilih Isomil Advance ${ }^{\circledR}$ maka bayi diikutkan dalam penelitian. Hal ini disebabkan karena penelitian ini bersifat observasi dan formula tidak disediakan oleh peneliti atau sponsor.

Bayi tidak diikutsertakan apabila ada dugaan 
hipersensitivitas atau intoleransi terhadap kedelai, gejala dugaan reaksi simpang disebabkan oleh infeksi atau penyebab lain, memiliki penyakit jantung, pernapasan atau penyakit sistemik lainnya, riwayat inkompatibilitas darah, bayi terinfeksi HIV, memiliki kelainan kongenital mayor, dan gangguan pencernaan serius atau bayi terdaftar sebagai subyek dalam studi klinis lainnya.

Setiap subyek diamati selama kurang lebih 4 minggu. Kunjungan dilakukan selama 3 kali yaitu kunjungan 1 pada saat pengambilan data awal, kunjungan 2 pada hari ke-14 \pm 3 hari, kunjungan 3 pada hari ke- $28 \pm 5$ hari. Subyek minimal datang pada kunjungan kedua untuk dapat dianalisis. Waktu kunjungan tindak lanjut diserahkan kepada masingmasing dokter peneliti. Penelitian ini telah lolos kaji etik dari Komite Etik FKUI pada tanggal 18 Juli 2011 dan terdaftar di clinicaltrials.gov, NCT01809951. Partisipasi orangtua bersifat sukarela dan mereka dapat sewaktu-waktu menarik diri dari penelitian ini.

Pada kunjungan awal dilakukan pencatatan seperti inisial nama, tanggal lahir, antropometri saat lahir, gejala klinis alergi susu sapi yang dialami, adanya gangguan pencernaan, frekuensi defekasi empat minggu terakhir, konsistensi tinja, dan riwayat obat-obatan yang dikonsumsi sebelum studi. Pada kunjungan berikutnya, data dikumpulkan data mengenai jumlah susu formula kedelai yang dikonsumsi, gejala klinis, dan penerimaan orangtua/pengasuh mengenai penggunaan susu formula kedelai dengan pengisian kuesioner oleh dokter peneliti berdasarkan keterangan dari orangtua.

Keseluruhan data dimasukkan ke dalam formulir penelitian. Data deskriptif diolah dan disajikan dalam bentuk tabel. Setiap gejala dengan atau tanpa hubungan sebab akibat dari penggunaan produk yang terjadi dalam kunjungan berikutnya dianggap sebagai reaksi simpang dan dilaporkan kepada sponsor dan organisasi riset dalam waktu yang ditentukan.

\section{Hasil}

Pada periode penelitian didapatkan 534 subyek dari 660 subyek yang dapat dianalisis. Penelitian ini dilakukan di beberapa kota besar di Indonesia. Subyek berasal dari Jakarta 320 orang bayi, Surabaya 132, Bali 80, Bandung 79, Yogyakarta dan Solo 49 orang (Gambar 1). Data demografis tertera pada Tabel 1.

Gejala klinis yang timbul sugestif akibat alergi susu sapi adalah gejala pada saluran napas $275(51,5 \%)$, kulit $260(48,7 \%)$, saluran cerna $210(39,3 \%)$, dan lain-lain $39(7,3 \%)$. Keluhan saluran napas ditandai antara lain dengan gejala batuk, napas berbunyi, dan pilek. Keluhan pada kulit ditandai dengan kemerahan pada kulit, dermatitis atopik, gatal, dan urtikaria. Sedangkan keluhan pada saluran cerna ditandai dengan keluhan diare, muntah, diare berdarah, dan konstipasi.

Sebagian besar orangtua puas dengan pemberian formula isolat protein kedelai tetap ingin melanjutkan pemberian formula isolat kedelai untuk anaknya, dan anak menyukai formula isolat protein kedelai. Menurut sebagian besar orangtua kondisi anak saat mengonsumsi formula isolat protein kedelai adalah baik (Tabel 2).

Alasan orangtua untuk melanjutkan atau menghentikan pemberian isolat protein kedelai $(n=511)$ adalah gejala klinis berkurang $(31,5 \%)$, gejala menghilang $(32,4 \%)$, anak menyukai formula $(20,2 \%)$, berat badan meningkat $(3,9 \%)$, anak tidak menyukai formula $(7,6 \%)$, tidak ada perubahan gejala klinis $(3,1 \%)$, mahal $(2,5 \%)$, alasan lain $(15,3 \%)$.

Pada pemantauan didapatkan gejala sugestif alergi susu sapi secara keseluruhan membaik dalam empat minggu (Tabel 3). Pola defekasi juga membaik dalam empat minggu (Tabel 4). Didapatkan $86 \%$ subyek dapat mengonsumsi formula isolat protein kedelai, $14 \%$ subyek mengalami reaksi simpang yang terdiri dari gejala saluran cerna (12\%) dan gejala di luar saluran cerna $(5,2 \%)$. Reaksi simpang tersebut merupakan gejala klinis baru yang timbul pada kunjungan kedua atau ketiga dan

Tabel 1. Data demografis subyek penelitian

\begin{tabular}{lc}
\hline Data demografis & Rerata $(\mathrm{SB}), \mathrm{n}=534$ \\
\hline Usia (bulan) & $7,85(1,83)$ \\
Berat badan saat kunjungan awal $(\mathrm{kg})$ & $7,99(1,23)$ \\
Tinggi badan saat kunjungan awal $(\mathrm{cm})$ & $67,83(6,32)$ \\
Berat lahir $(\mathrm{kg})$ & $3,14(0,339)$ \\
Panjang lahir $(\mathrm{cm})$ & $49,15(1,92)$ \\
\hline
\end{tabular}

Sari Pediatrí, Vol. 15, No. 4, Desember 2013 
Zakiudin Munasir dkk: Pasca-pemasaran formula isolat protein kedelai dengan gejala sugestif alergi terhadap protein susu sapi

Tabel 2. Penerimaan/opini orangtua mengenai pemberian formula isolat protein kedelai

\begin{tabular}{lc}
$(\mathrm{n}=534)$ & $\mathrm{n}(\%)$ \\
\hline Penerimaan/opini orangtua & \\
\hline Kepuasan orangtua & $449(84)$ \\
$\quad$ Puas & $55(10)$ \\
$\quad$ Netral & $30(6)$ \\
Tidak puas & \\
Rencana melanjutkan formula isolat protein kedelai & $444(83)$ \\
$\quad$ Ya & $57(11)$ \\
Ragu-ragu & $32(6)$ \\
Tidak & \\
Kondisi anak & $451(84)$ \\
Membaik & $72(14)$ \\
Biasa saja & $11(2)$ \\
Memburuk & \\
Anak menyukai formula isolat protein kedelai & $452(85)$ \\
Setuju & $53(10)$ \\
Netral & $29(5)$ \\
Tidak setuju &
\end{tabular}

Tabel 3. Gejala sugestif alergi susu sapi pada setiap kunjungan

\begin{tabular}{lccc}
\hline Gejala & $\begin{array}{c}\text { Kunjungan 1, } \mathrm{n}(\%) \\
(\mathrm{n}=534)\end{array}$ & $\begin{array}{c}\text { Kunjungan 2, } \mathrm{n}(\%) \\
(\mathrm{n}=534)\end{array}$ & $\begin{array}{c}\text { Kunjungan 3, } \mathrm{n}(\%) \\
(\mathrm{n}=294)\end{array}$ \\
\hline Saluran napas & $275(51,5)$ & $87(16,3)$ & $25(8,5)$ \\
Kulit & $261(48,9)$ & $53(9,9)$ & $16(5,4)$ \\
Saluran cerna & $209(39,1)$ & $38(7,1)$ & $6(0,2)$ \\
Lain-lain & $39(7,3)$ & $1(0,2)$ & $0(0)$ \\
\hline
\end{tabular}

Tabel 4. Karakteristik pola defekasi subyek penelitian

\begin{tabular}{lccc}
\hline Pola defekasi & $\begin{array}{c}\text { Kunjungan 1, } \mathrm{n}(\%) \\
\mathrm{n}=534\end{array}$ & $\begin{array}{c}\text { Kunjungan 2, } \mathrm{n}(\%) \\
\mathrm{n}=534\end{array}$ & $\begin{array}{c}\text { Kunjungan 3, } \mathrm{n}(\%) \\
\mathrm{n}=294\end{array}$ \\
\hline $\begin{array}{l}\text { Frekuensi defekasi } \\
<3 \text { kali/minggu }\end{array}$ & $68(12,7)$ & $71(13,3)$ & $32(10,9)$ \\
$>3 \mathrm{kali} /$ minggu & $306(57,3)$ & $421(78,8)$ & $247(84)$ \\
$>3$ kali/hari & $157(29,4)$ & $29(5,4)$ & $9(3,1)$ \\
Tidak diketahui & $3(0,6)$ & $13(2,4)$ & $6(2)$ \\
Konsistensi & & & \\
Keras & $45(8,4)$ & $29(5,4)$ & $22(7,5)$ \\
Berbentuk & $152(28,5)$ & $260(48,7)$ & $170(57,8)$ \\
Lunak & $292(54,7)$ & $227(42,5)$ & $96(32,7)$ \\
Berair & $41(7,7)$ & $7(1,3)$ & $2(0,7)$ \\
Tidak diketahui & $4(0,7)$ & $11(2,1)$ & $4(1,4)$ \\
Warna & & & \\
Kuning & $313(58,6)$ & $363(68)$ & $216(73,5)$ \\
Hijau & $114(21,3)$ & $84(15,7)$ & $43(13,9)$ \\
Coklat & $89(16,7)$ & $74(13,9)$ & $29(9,9)$ \\
Hitam & $9(1,7)$ & $1(0,2)$ & $1(0,3)$ \\
Tidak diketahui & $9(1,7)$ & $12(2,2)$ & $7(2,4)$ \\
\hline
\end{tabular}


belum tentu berhubungan langsung dengan pemakaian formula isolat protein kedelai. Tidak ditemukan adanya reaksi simpang berat pada penelitian ini.

\section{Pembahasan}

Kacang kedelai (Glycine max) telah dikonsumsi di Asia sejak lama. Kacang kedelai telah dikembangkan sejak tahun 2838 sebelum Masehi di Cina dan kemudian menyebar ke Korea, Jepang, India, dan negara-negara Asia Tenggara. Berbagai produk dapat dihasilkan dari kacang kedelai, antara lain minyak, tepung, kecap, tahu, tempe, penyedap alamiah dan susu formula. ${ }^{14,15}$

Formula isolat protein kedelai menjadi salah pilihan di beberapa negara untuk menjadi formula pengganti pada anak dengan alergi susu sapi. Banyak merk formula isolat protein kedelai beredar di Indonesia. Pemakaian formula ini adalah untuk anak-anak dengan intoleransi laktosa dan dapat digunakan pada anak dengan alergi susu sapi apabila anak tersebut memiliki masalah dalam ketersediaan formula hidrolisat ekstensif. Konsensus yang dibuat oleh UKK Alergi Imunologi, UKK Nutrisi dan Penyakit Metabolik, dan UKK Gastrohepatologi IDAI, menyebutkan bahwa pilihan utama formula pengganti pada anak alergi susu sapi adalah formula hidrolisat ekstensif. Namun apabila terdapat masalah pada ketersediaan atau biaya, maka formula isolat protein kedelai dapat diberikan dengan pemberitahuan kepada orangtua mengenai risiko alergi protein kedelai pada anak dengan alergi susu sapi. ${ }^{6}$

Isomil Advance ${ }^{\circledR}$ adalah salah satu merk formula isolat protein kedelai yang ada di Indonesia. Penelitian ini merupakan penelitian multisenter yang menilai tingkat penerimaan orangtua dan toleransi saluran cerna bayi yang diamati selama kurang lebih 4 minggu.

Kelemahan penelitian ini bersifat observasi dengan cara menegakkan diagnosis alergi susu sapi berdasarkan anamnesis serta pemeriksaan fisis awal, dan tidak selalu disertai dengan pemeriksaan laboratorium ataupun uji eliminasi dan provokasi. Namun, tingkat kesalahan diagnosis telah diperkecil dengan menentukan kriteria diagnosis klinis (dalam batasan operasional) yaitu dari anamnesis didapatkan asosiasi waktu (timbul gejala alergi bila minum susu sapi dan gejala menghilang bila susu sapi dieliminasi dari diet), adanya riwayat atopi dalam keluarga, terdapat beberapa sistem organ yang terlibat, uji alergi atau indikator inflamasi yang positif (bila dilakukan), eksklusi intoleransi laktosa, dan tidak ada respons pada pemberian obat-obatan simptomatik/kausal lain.

Pada penelitian ini dijumpai gejala sugestif alergi susu sapi adalah gejala pada saluran napas $(51,5 \%)$, kulit $(48,9 \%)$, dan saluran cerna $(39,1 \%)$. Hal ini sedikit berbeda dengan penelitian lain di luar negeri yang menemukan bahwa keluhan pada saluran cerna dan dermatitis atopik lebih banyak dibandingkan keluhan saluran napas. ${ }^{1}$ Namun, hal yang sama ditemukan pada penelitian di Indonesia oleh Mardiati, ${ }^{16}$ yang menemukan keluhan saluran napas lebih banyak dibandingkan keluhan saluran cerna dan kulit.

Tingkat penerimaan orangtua terhadap pemakaian formula isolat protein kedelai secara umum adalah cukup baik, sebagian besar orangtua pada penelitian ini juga ingin tetap melanjutkan pemberian formula isolat protein kedelai. Hal ini dapat dipahami karena sebagian besar gejala klinis subyek membaik dalam pemantauan dan yang juga penting subyek dapat menerima rasa formula ini. Hampir sebagian besar keluhan baik di saluran napas, saluran cerna, maupun kulit membaik dalam pengamatan empat minggu.

Beberapa masalah yang timbul dalam pemberian formula hidrolisat ekstensif adalah masalah ketersediaan, biaya, dan rasa. Masyarakat Indonesia yang tersebar di berbagai pulau, belum tentu mempunyai akses yang mudah terhadap formula hidrolisat ekstensif. Kalaupun tersedia, maka masalah harga menjadi kendala berikut. Rasa yang kurang enak juga mempunyai andil dalam pemberian formula. Pedrosa, $\mathrm{dkk}^{17}$ menemukan bahwa formula berbasis kedelai atau beras memiliki skor rasa yang lebih baik, diikuti oleh formula hidrolisat whey, dan formula hidrolisat whey-kasein.

Hal yang perlu diingat pada pemberian formula isolat protein kedelai adalah risiko alergi terhadap protein kedelai juga dapat terjadi pada anak alergi susu sapi. Berbagai penelitian menyebutkan angka alergi terhadap protein kedelai pada anak dengan alergi susu sapi. Dilaporkan bahwa alergi protein kedelai lebih tinggi pada anak dengan alergi susu sapi yang tidak dimediasi IgE dibandingkan anak dengan alergi susu sapi yang dimediasi IgE. ${ }^{18}$ Anak alergi susu sapi di bawah usia enam bulan juga memiliki risiko alergi protein yang lebih tinggi dibandingkan anak di atas usia enam bulan. ${ }^{19}$ Sebenarnya penelitian di Indonesia menunjukkan angka sensitisasi maupun alergi terhadap protein kedelai pada anak alergi susu sapi rendah yaitu $18 \%$ dan $0 \% .{ }^{20,21}$ Namun demikian, penjelasan kepada 
orangtua saat awal pemberian formula isolat protein kedelai tetap dibutuhkan.

Toleransi saluran cerna pemberian isolat protein kedelai juga cukup baik. Hal ini ditandai karakteristik defekasi yang semakin membaik dalam 4 minggu, yaitu semakin banyak subyek yang masuk dalam kelompok dengan frekuensi defekasi lebih dari tiga kali per minggu sampai kurang dari tiga kali per hari, dengan konsistensi yang berbentuk/lunak, dan berwarna kuning. Data tersebut menunjukkan bahwa pemberian isolat protein kedelai dapat memperbaiki keluhan saluran cerna pada pasien sugestif alergi susu sapi.

Reaksi simpang yang serius tidak ditemukan pada penelitian ini. Formula dapat ditoleransi dengan baik oleh $86 \%$ subyek. Keluhan yang timbul pada $14 \%$ subyek lainnya tidak dapat disimpulkan sebagai akibat langsung dari formula isolat protein kedelai, karena reaksi yang dianggap reaksi simpang adalah reaksi yang baru timbul pada kunjungan kedua atau ketiga. Keterbatasan penelitian ini, reaksi simpang yang terjadi belum dievaluasi lebih lanjut apakah langsung berhubungan dengan formula yang dikonsumsi atau karena penyebab lain.

\section{Kesimpulan}

Pada penelitian ini didapatkan tingkat penerimaan orangtua dan toleransi saluran cerna yang baik terhadap pemberian formula isolat protein kedelai kepada bayi dengan gejala sugestif alergi terhadap protein susu sapi. Formula isolat protein kedelai cukup aman diberikan sebagai formula alternatif pengganti, pada anak dengan alergi susu sapi.

\section{Ucapan terima kasih}

Ucapan terima kasih disampaikan kepada seluruh tim peneliti yang terlibat pada penelitian ini di kota Jakarta, Surabaya, Bandung, Denpasar, Yogyakarta, dan Solo. Serta kepada PT.Abbott Indonesia yang telah membiayai penelitian ini

\section{Daftar pustaka}

1. Kattan JD, Cocco RR, Jarvinen KM. Milk and soy allergy. Pediatr Clin North Am. 2011; 58: 407-26.
2. Høst A, Koletzko B, Dreborg S, Muraro A, Wahn U, Aggett P, Bresson JL, Hernell O, Lafeber H, Michaelsen KF, Micheli JL, Rigo J, Weaver L, Heymans H, Strobel $S$, Vandenplas Y. Dietary products used in infants for treatment and prevention of food allergy. Joint Statement of the European Society for Paediatric Allergology and Clinical Immunology (ESPACI) Committee on Hypoallergenic Formulas and the European Society for Paediatric Gastroenterology, Hepatology and Nutritionc(ESPGHAN) Committee on Nutrition. Arch Dis Child. 1999; 81: 80-4.

3. American Academy of Pediatrics. Committee on Nutrition. Hypoallergenic infant formulas. Pediatrics. 2000; 106: 346-9.

4. Kemp AS, Hill DJ, Allen KJ, Anderson K, Davidson GP, Day AS, Heine RG, Peake JE, Prescott SL, Shugg AW, Sinn JK. Guidelines for the use of infant formulas to treat cows milk protein allergy: an Australian consensus panel opinion. Med J Aust. 2008; 188: 109-12.

5. Lee BW, Aw M, Chiang WC, Daniel M, George GM, Goh EN, Han WM, Lee ML, Leong KP, Liew WK, Phuah KY, Shek L, Van Bever H. Academy of medicine, Singapore-Ministry of Health clinical practice guidelines: management of food allergy. Singapore Med J. 2010; 51: 599-607.

6. UKK Alergi Imunologi, UKK Nutrisi dan Penyakit Metabolik, UKK Gastrohepatologi Ikatan Dokter Anak Indonesia. Rekomendasi Ikatan Dokter Anak Indonesia. Diagnosis dan tata laksana alergi susu sapi. Jakarta; BP IDAI: 2010.

7. Businco L, Bruno G, Giampietro PG, Cantani A. Allergenicity and nutritional adequacy of soy protein formulas. J Pediatr. 1992;121:S21-8.

8. Seppo L, Korpela R, Lonnerdal B, Metsaniitty L, Juntunen-Backman K, Klemola T, dkk. A follow up study of nutrient intake, nutritional status, and growth in infants with cow milk allergy fed either a soy formula or an extensively hydrolyzed whey formula. Am J Clin Nutr. 2005; 82: 140-5.

9. Mendez MA, Anthony MS, Arab L. Soy-based formulae and infant growth and development: a review. J Nutr. 2002; 132: 2127-30.

10. Steichen JJ Tsang RC. Bone mineralization and growth in term infants fed soy-based or cow milk-based formula. J Pediatr 1987; 110: 687-92.

11. Merritt RJ, Jenks BH. Safety of soy-based infant formulas containing isoflavones: the clinical evidence. J Nutr 2004; 134: 1220S-24S.

12. ESPGHAN Committee on Nutrition, Agostoni C, 
Zakiudin Munasir dkk: Pasca-pemasaran formula isolat protein kedelai dengan gejala sugestif alergi terhadap protein susu sapi

Axelsson I, Goulet O, Koletzko B, Michaelsen KF, dkk. Soy protein infant formulae and follow-on formulae: a commentary by the ESPGHAN Committee on Nutrition. J Pediatr Gastroenterol Nutr. 2006; 42: 35261.

13. Bhatia J, Greer F. Use of soy protein-based formulas in infant feeding. Pediatrics. 2008;121;1062-8.

14. Quak SH, Tan SP. Use of soy-protein formula and soyfood for feeding infants and children in Asia. Am J Clin Nutr 1998;68:1444S-6S.

15. Siregar SP. Alergi makanan pada bayi dan anak. Sari Pediatri 2001;3:168-74.

16. Mardiati I. Gambaran klinis dan immunoglobulin E spesifik pada bayi dan anak dengan alergi susu sapi. Tesis. Departemen Ilmu Kesehatan Anak FKUI, 1998.

17. Pedrosa M, Pascual CY, Larco JI, Esteban MM. Palatability of hydrolysates and other substitution formulas for cow's milk-allergic children: a comparative study of taste, smell, and texture evaluated by healthy volunteers. J Investig Allergol Clin Immunol. 2006;16:351-6.

18. Zeiger RS, Sampson HA, Bock SA, Burks AW, Harden $\mathrm{K}$, Noone S, dkk. Soy allergy in infants and children with IgE-associated cow's milk allergy. J Pediatr 1999; 134: 614-22.

19. Klemola T, Vanto T, Juntunen-Backman K, Kalimo K, Korpela R, Varjonen E. Allergy to soy formula and to extensively hydrolyzed whey formula in infants with cow's milk allergy: a prospective, randomized study with a follow-up to the age of 2 years. J Pediatr. 2002; 140: 219-24.

20. Muktiarti D, Munasir Z, Tumbelaka AR. Soy protein sensitization in cow's milk allergy patients. Paediatr Indones 2007; 47: 78-82.

21. Santi A, Juffrie M, Sumadiono. IgE-mediated soy protein sensitization in children with cow's milk allergy. Paediatr Indones 2012; 52: 67-71. 